\title{
American Cultural Imperialism in 1960s Japan as Seen in Haruki
}

\section{Murakami's Norwegian Wood}

\author{
Bhakti Satrio Nugroho \\ American Studies Master's Program, Universitas Gadjah Mada, Indonesia \\ bhakti.landt@gmail.com
}

DOI: $10.20884 / 1 . j 1 i .2020 .11 .1 .2361$

\begin{abstract}
Article History:
First Received:

\section{ABSTRACT}

$17 / 02 / 2020$

Final Revision:

Haruki Murakami is mostly well-known for his many works and is considered

04/06/2020 as one of the most influential writers in Japan. One of his greatest works is a nostalgic novel Norwegian Wood which named after The Beatles song,

Available online: Norwegian Wood (This Bird Has Flown) in their album Rubber Soul (1965). It becomes \#1 bestselling novel in Japan. This novel resembles many aspects

$25 / 06 / 2020$ of "Americanization" of Japanese young adult life in the 1960s Japan which was strongly influenced by American popular culture. Many Japanese in this novel adopt Western culture which was popular in the United States. Hollywood and American music became central part of the main story in Haruki Murakami's Norwegian Wood. By using cultural imperialism theory, this research focuses on the imposition and glorification of American culture in 1960s Japan which is celebrated as part of central storyline. American cultural imperialism can be seen in dissemination and glorification of American popular culture and American way of life (lifestyle) among Japanese young adults. Furthermore, they create many social and cultural changes. It is further helped by the post-war Japanese's inferiority after losing to the United States in World War II. In fact, Western thoughts and beliefs are part of "American gifts" during U.S occupation which disseminate even after the end of occupation. Thus, this historical postcolonial relationship between Japan (as the colonized) and the United States (as the colonizer) massively supports "Americanization" of 1960s Japan which results a loss of identity and a cultural dependency of Japan toward the United States.
\end{abstract}

Keywords: 1960s Japan, American popular culture, cultural imperialism, post-colonialism, transnational

\section{INTRODUCTION}

In the 1960s, Western popular music, especially American, and other popular culture started spreading around the world. The Beatles, for instance, became a cultural phenomenon in the 1960s especially in the United States. This phenomenon called as Beatlemania which refers to mass outburst of The Beatles' fans which mostly consisted of women (Ehrenreich et al, 1992). Although they were originally from Liverpool, England, The Beatles gained massive popularity in the United States due to their American music influences. They became one of the most 
popular American Rock ' $\mathrm{n}$ Roll icons, the genre which originated and evolved in late 1940s (Mayberry, 2011). Since their massive popularity, The Beatles, which consisted of Ringo Starr, George Harrison, John Lennon and Paul McCartney, became an icon of Western popular culture which represented the dissemination of Western popular culture around the world. During 1960s, their albums such as Rubber Soul (1965), Revolver (1966) and Sgt Pepper's Lonely Hearts Club Band (1967) marketed around the world. In Japan, Haruki Murakami, a famous Japanese novelist, named his novel after The Beatles song, Norwegian Wood (This Bird Has Flown), written by John Lennon and Paul McCartney in Rubber Soul album.

Haruki Murakami's Norwegian Wood is a nostalgic novel which became number 1 bestselling novel in Japan. It has sold over 4 million copies from the first release in 1987. However, the English version of this novel was firstly released in 2000. In fact, this song is often described in the novel as favorite song for a character named Naoko who has a special relationship with the main character, Toru. In short, this novel focuses on the Japanese young adults' life in the 1960s Japan which consumed many Western popular culture and even Western products, in this case, American products.

In the 1960s, Japan began to transform into developed country after losing in World War II from Allies. Around fifteen years after its defeat, Japan experienced some social and cultural changes which were brought by the United States during their occupation in 1945-1952. It was also the period after Allied occupation of Japan in 1945 until 1952 which codenamed as Operation Blacklist (Takemae, 2002). This occupation was led by Douglas MacArthur, the Supreme Commander for the Allied Powers (SCAP), with support from the British Commonwealth. This period frequently said in some references as post U.S occupation of Japan (because the occupation was primarily led by U.S) which also becomes very valuable attempt to examine from various perspectives how the United States had penetrated into Japanese culture and customs since the end of the World War II (Yoshimi, 2003). At this time, the local Japanese culture began to fade away, and as the result, the Japanese culture adopted Western culture brought by Allied power, especially the United States.

Furthermore, these social and cultural changes continued even after the departure of the Occupation forces in 1952. In fact, in the mid-1960s, American popular culture, especially music, gained its massive popularity (Achterberg et al., 2011). Japan was one of the opened recipient countries by consuming many American popular cultures including music, literature, fashion, and lifestyle due to its historical relationship with the United States. Using mass media which controlled and ruled by the United States at that time, the dissemination of American popular cultures in Japan is inevitable. Moreover, the historical postcolonial relationship between 
both the United States (as the self) and Japan (as the other) became one of the most influential aspects that support the "Americanization" in Japan.

In Haruki Murakami's Norwegian Wood, there are many issues that can be found such as sexuality and French existentialism issues which have already analyzed by Tsang Yat-Him from The Chinese University of Hong Kong (2011) and Kieran James et al from some Universities in Australia (2011). However, despite these dominant issues, there is a post colonialism issue dealing with American cultural imperialism. This issue can be categorized as an alternative issue to analyze the hegemonic American cultural imperialism in the 1960s Japanese young adult characters' behavior in this novel. By using John Tomlinson's cultural imperialism, the researcher tries to emphasize the research to the imposition of Western cultures in the 1960s Japanese society.

\section{THEORETICAL FRAMEWORK}

This research is under Transnational American Studies which utilizes postcolonialism as its approach and cultural imperialism as its theory. Transnational American Studies examines the American influences beyond geographical border which conceptualizes borders as performative phenomena (Kim \& Robinson, 2017). Post-colonialism is an intellectual direction that exists around the middle of the 20th century (Childs \& Williams, 1997). It mainly developed to the time after colonialism as colonial countries became independent. Nowadays, post-colonialism aspects can be found not only in sciences concerning history, literature and politics, but also in approach to culture and identity of both the countries that were colonized by former colonial powers.

Meanwhile, Tomlinson defines cultural imperialism as a critical discourse which operates by representing the cultures whose autonomy it defends in its own (dominant) Western cultural terms. In this case, it can be understood as "the idea of the invasion of an indigenous culture by a foreign one" (Tomlinson, 1991). It indicates that one or more cultures are imposing themselves, more or less consciously, on other cultures thereby destroying local culture in whole or more likely in part (Tomlinson in Ritzer, 2011). It means that it is not also seen as imposing but also as destroying the local culture. Tomlinson further tries to substitute 'local' in the place of 'indigenous' and proposes the scope of local culture as that being of nations. By establishing this scope, the idea that is emphasized would be national cultural identity and how cultural imperialism threatens it. Furthermore, Herbert Schiller further adds deeper understanding about cultural imperialism by saying, 
The concept of cultural imperialism today [1975] best describes the sum of the processes by which a society is brought into the modern world system and how its dominating stratum is attracted, pressured, forced, and sometimes bribed into shaping social institutions to correspond to, or even promote, the values and structures of the dominating centre of the system. The public media are the foremost example of operating enterprises that are used in the penetrative process. For penetration on a significant scale the media themselves must be captured by the dominating/penetrating power. This occurs largely through the commercialization of broadcasting. (Schiller, 1976)

By this definition, it means that cultural imperialism does not only focus on the dependency of native culture toward dominant (West) culture but also focuses on the penetration or imposition of dominant culture toward the native culture which brings the native culture into modern world system.

Furthermore, this penetration or imposition promotes the values and structures of the dominating center of the system. Furthermore, the penetrative process of cultural imperialism is significantly supported by the media which is controlled by dominant power. In other words, the media plays significant role in cultural imposition which helps the dissemination of dominant culture including values, pop culture, behavior, lifestyle and other social and cultural aspects. These aspects are accepted by indigenous or local culture because the dominant power has already taken control of the media. Thus, cultural imperialism is often irresistible for subordinate or subaltern culture which has less power toward the dominant culture. It creates cultural dependency to the dominant culture which later also destroys the local culture.

\section{METHOD}

The qualitative research is used to present the data analysis since this method emphasizes on the researcher's interpretation toward the data. It further focuses on the qualities of entities, processes and meanings that are not experimentally examined or measured in terms of quantity, amount, intensity or frequency (Creswell, 2009). It allows the researcher to examine this less dominant issue within the novel to make deeper analysis, especially dealing with American cultural imperialism issue. It also can be used to understand this cultural phenomenon as complex as it can to create further analysis. The data are used in this research are divided into two: primary data which are the quotations from Haruki Murakami's Norwegian Wood and secondary data which are the historical and theoretical references to support American cultural imperialism in the 1960s Japan. In conducting this research, there are three main steps: (1) data 
reduction which focuses on the dialogue and narration which relate to depictions of American cultural imperialism in the 1960s Japan, (2) data interpretation focuses on interpretation of the data, and (3) data conclusion focuses on drawing conclusion from the result of the research.

\section{RESULTS AND DISCUSSION}

This discussion mainly focuses on the American cultural imperialism in the 1960s Japan and the cultural transformation within the society as seen in Haruki Murakami's Norwegian Wood. However, before discussing the 1960s American cultural impositions and glorifications, we need to discuss the historical events related to "Americanization/Westernization" in Japan. The first Westernization of Japan occurred in Meiji Restoration. In this period, with the help of Western influence, many policies were made in many aspects including industrialization, militarization and education in order to modernize Japan (Kitayama, 1990). However, since 1930s, Japan underwent “Japan's Pan Asianism” ideology which also called as "anti-Western movement" or "anti-Western imperialist" (Shillony, 1991). The idea of this ideology was to return Japan to Asia rather than West. It was applied by abandoning the diplomatic cooperation with West and prohibiting the symbols of Western culture in Japan (Miller, 2004). It made many cultural transitions which mostly declining the dissemination of Western culture in Japan.

However, in 1945-1952, after defeated in World War II, Japan was occupied by the Supreme Commander for the Allied Powers (SCAP), led by Douglas MacArthur, with support from the British Commonwealth. It became a very valuable attempt to examine from various perspectives how the United States had penetrated into Japanese culture and customs (Yoshimi, 2003). In Haruki Murakami's Norwegian Wood which set in the 1960s, more than a decade after U.S occupation, Japanese young adults seemed to enjoy and celebrate the democratic ways of life and modernization re-brought by the colonizer (the United States). There are two important findings of hegemonized Japanese society which can be seen in this novel: the dissemination and glorification of American popular cultures and American lifestyle.

\section{American Popular Cultures in Haruki Murakami’s Norwegian Wood}

In this novel, American popular cultures such as pop and jazz music become one of the influential issues through the story. In fact, the title of this novel itself is basically named after one of The Beatles song entitled Norwegian Wood (This Bird Has Flown) in Rubber Soul album (1965). During Toru's and Naoko's visit in Ami Hostel, Reiko sings and plays Western music with her guitar, 
"Reiko moved on to the Beatles, playing "Norwegian Wood", "Yesterday", "Michelle", and "Something". She sang and played "Here Comes the Sun", then played "The Fool on the Hill". I laid seven matches in a row.

"Seven songs," said Reiko, sipping more wine and smoking another cigarette. "Those guys sure knew something about the sadness of life, and gentleness." By "those guys" Reiko of course meant John Lennon, Paul McCartney and George Harrison. After a short breather, Reiko crushed her cigarette out and picked up her guitar again. She played "Penny Lane", "Blackbird", "Julia", "When I'm 64", "Nowhere Man", "And I Love Her", and "Hey Jude". (Murakami, 2000)

Stevens (in Matsue, 2015) states the popularity of Western popular culture in Japan, mostly influenced by Allied occupation which led by U.S. It happened because during the occupation, U.S controlled the mass media and dissemination of songs on the radio and recordings. Hence, Western popular music was widely consumed by the local young adults until post-occupation era. Furthermore, post-war Japanese society dramatically adopted English by consuming Western music which was frequently aired in Radio. It was indicated by the popularity of foreign programs in NHK (Nippon Hoso Kyokai or Japanese Broadcasting Corporation) such as "English Conversation" and "Come, Come English" hosted by Hirakawa Tadaichi (Yoshitake, 2008). In this case, post war Japanese began to assume that American ways of thinking and living were superior for Japanese and attempted to receive them. It also made the usage of English as the United States national language, increased in post war Japanese society.

Besides The Beatles and other Western popular music such as The Drifters, The Beach Boys, Bob Dylan, American Jazz music also play significant role in Haruki Murakami's Norwegian Wood. This can be seen by many American jazz musician songs which are consumed by 1960s Japanese young adults in this story. The songs by American jazz musician such as Bill Evans, Ornette Coleman, Bud Powell, Getz and Charley Bird, Thelonious Monk and Henry Mancini are consumed by 1960s Japanese young adult in this novel. In this case, American jazz musicians who are often described in this novel are Henry Mancini and Bill Evans. Their works are part of Naoko's collection in the novel (Murakami, 2000).

Furthermore, not only Western popular music, but Japanese people also began to consume Western goods. Furthermore, goods which are related to U.S became an object of consumption (Yoshimi, 2008). These goods included Western literary works which have already been translated into Japanese language. In Haruki Murakami's Norwegian Wood, there are many American novels were consumed by 1960s Japanese young adults. Moreover, American novels such as John Updike's, Scott F. Fitzgerald's, Joseph Conrad's, Truman Capote's, and Raymond 
Chandler's play a significant influence in the story and consumed by Toru and Nagasawa. In fact, Toru seems to be influenced by Scott F. Fitzgerald's The Great Gatsby and he adores Gatsby characterization,

At 18 my favourite book was John Updike's The Centaur, but after I [Toru] had read it a number of times, it began to lose some of its initial lustre and yielded first place to The Great Gatsby. Gatsby stayed in first place for a long time after that. I would pull it off the shelf when the mood hit me and read a section at random. It never once disappointed me. There wasn't a boring page in the whole book. I wanted to tell people what a wonderful novel it was, but no one around me had read The Great Gatsby or was likely to. Urging others to read F Scott Fitzgerald, although not a reactionary act, was not something one could do in 1968. (Murakami, 2000)

This finding shows that Toru has attracted with American novels since he was 18 years old by consuming The Centaur and then followed by Scott F. Fitzgerald's The Great Gatsby. By this definition, it is clear enough that America have massive influences for the development of Western culture in the 1960s Japan especially for Japanese young adults. The United States culturally hegemonize post-war Japanese society by controlling the mass media during and even after the occupation. As it is said in Tomlinson's notion that media is a significant tool for the colonizer (the United States) to impose their ideology and culture to the colonized (Japan). In fact, David Kaplan states that the purpose of reintroducing Western cultures to Japan is to avoid U.S occupied countries (such as Korea Republic, West Germany, and Japan) from communists influence in the Cold War period (1997). In this case, Western popular cultures such as music and literary works were considered as one of the most effective ways to psychologically avoiding the Japanese people from communist influence. This propaganda was applied by controlling mass media such as radio, film, television, and bookstore. This media control by the United States has massive impact for post-war Japanese society which can also be seen in this novel.

\section{American Lifestyle in Haruki Murakami’s Norwegian Wood}

Besides the hegemony of American popular culture in the 1960s Japan, Haruki Murakami’s Norwegian Wood also depicts the cultural and social changes on Japanese lifestyle which has already been massively influenced by American lifestyle. In dating and sexual relationship, for instance, the young adult characters such as Toru, Naoko, and Reiko experience dating as part of their love relationship. 
Naoko called me the following Saturday, and that Sunday we had a date. I [Toru] suppose I can call it a date. I can't think of a better word for it. As before, we walked the streets. We stopped somewhere for coffee, walked some more, had dinner in the evening, and said goodbye. (Murakami, 2000)

In this case, in the 1960s Japan, Japanese young adults began to adopt Western lifestyle including the concept of dating. Western-style dating including other activities such as dancing, watching movies and drinking coffee were popular among young Japanese couples (McLelland, 2010). In fact, during U.S occupation, according to sexologist Takahashi Tetsu, (in McLelland, 2010), the occupation forces had to instruct the police that kissing was no longer to be considered an offence against public decency. These erotic displays affected Japanese people in different ways in post-war era. Furthermore, this novel also depicts the "pre-marital sex culture" among young adults that also happened in United States since 1950s (Crowe et al (ed.) 2010). Thus, the love relationship among Toru and Naoko, for instance, consists of pre-marital sex which was used to be taboo in Japanese culture.

In fact, dating was also strange for most Japanese because traditional Japanese marriage was based on match making which is called "Miai" or "Omiai". It is a traditional method to find a spouse in Japan before U.S occupation. It is an arranged meeting between two people looking for someone to marry. During this period, marriage was an agreement between two families, and children (especially girls) had no right to choose their own spouse. This system remained at least until the arrival of American soldiers in postwar Japan (Davies \& Ikeno, 2002). Thus, cultural changes which were imposed by the United States during and after occupation to post-war Japanese society by controlling mass media, creates an erosion or even disappearance of traditional fundamental Japanese culture. As it is said by Tomlinson that cultural imperialism of the colonizer (the United States) can be considered as the idea of the invasion of an indigenous culture by a foreign one (Tomlinson. 1991). It means that the dissemination of American way of life in occupied Japan create massive impact on indigenous Japanese culture which became less followed by their own citizens.

Meanwhile, 1960s Japanese women also celebrate a gift from U.S occupation which is women's enfranchisement. As it is said before that during U.S occupation Japan had received the "four presents" which are respect for human rights, gender equality, freedom of speech, and women's enfranchisement. Lisa Yoneyama (2005) explains that the granting of rights to women played an important role in Japanese society. In this case, women received the right to vote as well as the right to work as industrial workers and professionals. Hence, Japanese women have adopted the Western approach love and marriage rather than followed their parents' choice. In 
addition, women have also adopted Western fashion and lifestyle. The definition of women's enfranchisement (or usually called as women's liberation and women's suffrage) is literary the right of women to vote in elections which was already applied since the late $19^{\text {th }}$ century in Western countries (Dubois, 1998). However, the definition of women's enfranchisement is not only limited to the right to vote but it also implies the gender equality between men and women. This notion was introduced to against the discrimination toward women in the society. In the United States, this notion was applied in 1920. Since this period, Western women became no longer socially submissive. During U.S occupation, Japan was infused this ideology by the colonizer (the United States).

Before U.S occupation, Japanese women have to follow ryosaikenbo, which means "good wife, wise mother". It was a cultural value toward the concept of Japanese women that was coined by Nakamura Masanao during Meiji period which constructed them as submissive wife who master some domestic skills such as cooking, sewing and childbearing (Sievers, 1983). It believes that childbearing was considered as a patriotic duty (Robertson, 2002). It means that Japanese women previously created to be good wife with good habit. It was clearly opposite of the men who are regarded as a symbol for role action and rational enlightenment (Uno in Goldstein-Gidoni, 1999). This cultural value finally declined during U.S occupation in Japan. Then, Japanese women entered new age of feminism which was introduced by the United States. This means that before U.S occupation, Japanese women were created to be housewife rather than professional workers.

In this novel, many Western cultures are adopted by 1960s Japanese women. In marriage, for instance, Japanese women no longer rely on arranged marriage, Omiai. It can be seen in Norwegian Wood when Toru and Naoko have a date, in fact, they conduct pre-marital sex which used to be taboo things for pre-war Japanese society. Moreover, for Japanese young adult woman like Reiko, being virgin in 25 years old becomes strange. "I [Reiko] remained a virgin until the day I married. I was 25 years old! Can you believe it?" (Murakami, 2000). Reiko's expression toward her virginity implies that in the 1960s, most of Japanese women have lost their virginity before their marriage. It means that premarital sex become very common in the 1960s Japanese young adult society. Reiko feels that remain a virgin until the day she married is something uncommon. It also means that losing her virginity before her marriage by doing premarital sex is commonly done by a certain group people in Japan, in this case, Japanese young adults. The celebration of sex liberation is part of "Americanization" in modern days of Japan. 
Meanwhile, in Haruki Murakami's Norwegian Wood, a modern Japanese woman is also culturally allowed to smoke as well as what a man does. In this case, Reiko is a smoking woman who does not care and worry about the traditional beliefs of ryosaikenbo,. Before the advent of U.S occupation, women smokers were considered as unfeminine because smoking was considered as a harmful behaviour for children. It means that the existence of Japanese women smokers were violated this concept of ideal motherhood (ryosaikenbo,) (Gaouette, 1998) However, the smoking habit for Japanese women appeared during U.S occupation in Japan.

This cultural imperialism of |American custom is supported by the fraternization between U.S. soldiers and Japanese women panpan girls during the occupation which involved public displays of intimacy, the exchange of cigarettes, chewing gum and chocolate. American soldiers built relationship with Japanese young women by offering them U.S cigarettes, chewing gum or chocolate bars (Sakamoto, 2010). Therefore, it is very obvious that the dissemination of U.S cigarette, chewing gum and chocolate among Japanese women was introduced by American soldiers during U.S occupation period. Moreover, it also means that Japanese women's smoking habit was considered as common habit since this period. Thus, for late Japanese young adult woman like Reiko, celebrating American way of life is common and there is nothing to worry about. The depiction of female smokers in mass media which was controlled by Western authorities influences and affects 1960s Japanese young adults' life. West, in this case, the United States becomes proper model for modern Japan. It is the right way of life for universal culture as they assume. 1960s Japanese women no longer adopt their own belief of ryosaikenbo.

Meanwhile, in fashion, both 1960s Japanese male and female no longer adopt traditional clothes. In this case, in post-war Japan, American popular culture including modern Hollywood style became a central model for Japanese people, especially for youth or young adult. Since the occupation, this customary clothing then spread and followed by Japanese people, "Young Japanese women known as pan-pan girls began to dress in the styles of modern Hollywood in the hope of enjoying a romantic liaison with a GI [American soldiers]" (Cope, 2007). Previously, Western fashion (yofuku) was firstly introduced in Meiji Restoration period in the end of shogunate in Japan in order to implement Western concepts of industrialization, militarization and education (Kitayama, 1990). However, for most of Japanese, except by military and noble people from high social class which (Slade, 2009), they tended to wear Japanese traditional clothes such as as kimono (literary means "something worn") and monpe (traditional work pantaloons) rather because Western cloth was not part of traditional norm at that time (Kawamura, 2006). As it has already stated U.S occupation had a major influence to Japanese 
fashion in post-war era. It means that Japanese no longer wear Japanese traditional clothes in their daily life.

In Haruki Murakami's Norwegian Wood, the depiction about 1960s Japanese men fashion can be seen in some narrations, "Fifteen minutes of walking and I [Toru] was sweaty enough to take off my thick cotton shirt and go with a T-shirt." (Murakami, 2000) and "Late in the afternoon I [Toru] showered and shaved and put on fresh clothes a polo shirt and cotton jacket." (Murakami, 2000). Shirt is historically a cloth that originally came from European (Western) dress in the seventeenth century (Rosenthal, 2009). This dress is often associated to Western culture which appears in mass media and worn by many American pop culture figures at that time. In fact, Toru wears many innovated shirts such as cotton shirt, T-shirt and polo shirt. These are huge evidences that the United States culturally impose this fashion style abroad especially for post occupied Japan which has been hegemonized and made the United States as role model. As same as male characters, female characters such as Naoko, Midori, Reiko and Hatsumi also wear Western-style clothing such as shirts (sweatshirt, polo shirt, and T-shirt), blouse, coat (duffel and balmacaan), sunglasses and jeans. In fact, there are no female characters who dress in kimono during the story, "Naoko had rolled the sleeves of her light grey sweatshirt up to her elbows." (Murakami, 2000), "Midori changed into a polo shirt and skirt." (Murakami, 2000) and "Reiko wore a pale blue cardigan over her shirt and walked with her hands shoved in her jeans pockets" (Murakami, 2000). These evidences show that these characters prefer to wear innovated shirt such as sweatshirt and polo shirt in their daily life. This fashion styles that were worn by 1960s Japanese male and female can be huge evidence that Japan underwent major transition and tend to mimic Western culture. It is a legacy of U.S occupation which can be considered as colonization of Japan. In this case, 1960s Japan is culturally imperialized by the United States.

The depictions of American popular culture and Western way of life which adopted by 1960s Japan can be considered as American cultural imperialism which happens in postoccupied Japan. U.S occupation leaves its legacy to modern Japan that, as Tomlinson has explained, destroys their indigenous culture. It creates an erosion of identity as a nation, in this case, as an East nation which used to hate Westernization (during Japan's Pan Asianism). The mass media that are controlled by the Western countries is one of the reasons why 1960s Japanese young adults tend to adopt Western culture rather than maintaining their own culture. The influential American popular figures such as Bob Dylan, Bill Evans, Thelonious Monk, The Beach Boys and The Beatles who appeared in mass media and fictional Western characters in 
John Updike's, Scott F. Fitzgerald's, Joseph Conrad's, Truman Capote's, and Raymond Chandler's novels, embrace Western beliefs and ideologies dealing with modernity and democracy. Thus, the historical post-colonial relationship and the popularity of American popular culture during the 1960s, drive modern Japanese society to be hegemonized massively by American culture. Therefore, there is not only economic and political dependency between Japan and the United States in the 1960s (post World War II) but also there is cultural dependency as well. As it is said before, media becomes important tool of cultural imperialism which proclaims the superiority of the West upon the inferiority of East. It invades American culture into Japanese culture and destroys the fundamental core of the society including attitude, manner, belief and tradition. As the result, post-war Japan have experienced a loss of identity and an erosion of culture which gradually replaced by Western culture.

\section{CONCLUSION}

In conclusion, Haruki Murakami's Norwegian Wood consists of two important findings of cultural imperialism: the dissemination and glorification of American popular cultures and American lifestyle. American popular cultures such as pop and jazz music become one of the influential issues through the story due to its popularity in the 1960s. In fact, the mass media such as radio, newspaper, movie theater, and bookstore were controlled by United States in order to democratize and demilitarize post-war Japan. Therefore, many American popular culture figures such as Bob Dylan, The Beach Boys and The Beatles have become role model and idol for 1960s Japanese young adults. Furthermore, Western or, in this case, American way of life is considered as thriving compared to Japanese own lifestyle. Many characters in this novel experience "Americanization" in their lifestyle regarding sexuality, dating, women's enfranchisement, and fashion. For instance, smoking habit for women is no longer taboo since ryosaikenbo, is no longer adopted by these female characters. Thus, it can be concluded that 1960s Japanese in Haruki Murakami's Norwegian Wood celebrate the advent of modernization through mass media and historical postcolonial relationship with United States. They were hegemonized by the previous enemy due to their inferiority after losing in World War II which results the loss of indigenous' identify and cultural dependency toward the United States. 


\section{REFERENCES}

Achterberg, P., Heilbron, J., Houtman, D., \& Aupers, S. (2011). A Cultural Globalization of Popular Music? American, Dutch, French, and German Popular Music Charts (1965 to 2006). American Behavioral Scientist, 55 (5), 589-608

Childs, P., \& Williams, P. (1997). An Introduction to Post-Colonial Theory. New York: Routledge.

Cope, J. (2007). Japrocksampler: How The Post-War Japanese Blew Their Minds on Rock N' Roll. London, New York and Berlin: Bloomsbury Publishing.

Creswell, J. (2009). Research Design: Qualitative, Quantitative, and Mixed Methods Approaches. Los Angeles: SAGE Publication.

Crowe, F., Hill, E., \& Hollingum, B. (Eds.) (2010). Sex and Society Volume 3. Malaysia:

Marshall Cavendish Corporation.

Davies, R., \& Ikeno, O. (2002). The Japanese Mind: Understanding Contemporary Japanese

Culture [Ice Cream Reader] http://bookzz.org EPUB File Retrieved on Saturday, June 25, 2016.

Dubois, E. (1998). Woman Suffrage and Women's Rights. New York and London: New York University Press.

Ehrenreich, B., Hess, E., \& Jacobs, G. (1992). ”Beatlemania: A Sexually Defiant Consumer Subculture?” In K. Geider \& S. Thornton, The Subcultures Reader, Routledge: New York.

Gaouette, N. (1998). "Japan Ads Sell Women On Smoking Despite Ban". The Christian Science Monitor. Retrieved on August 28, 2019, from https://www.csmonitor.com/1998/0309/030998.intl.intl.1.html

James, K., James, L., James, E., \& Briggs, S. (2011). Tales from the Hard Side": A French Existentialist Perspective on Haruki Murakami's Norwegian Wood. Journal of English and Literature, 2 (6), 128-143

Kaplan, D. (1997). U.S. Propaganda Efforts in Postwar Japan. Japan Policy Research Institute. Retrieved on August 28, 2019, from http://www.jpri.org/publications/critiques/critique_IV_1.html

Kawamura, Y. (2006). Japanese Fashion. Retrieved March 30, 2016, from http://fashionhistory.lovetoknow.com/clothing-around-world/japanese-fashion 
Kim, S. \& Robinsn, G. (2017). Introduction: Transnational American Studies in the "Age of Trump". Journal of Transnational American Studies, 8 (1). 1-14

Kitayama, A. (1990). Historical Changes in the Objectives of Japanese Music Education. The Quarterly, 1 (4), 32-37

Matsue, J. (2015). Focus: Music in Contemporary Japan. United Kingdom: Routledge.

Mayberry, E. C. (2011). Sam Phillips, Elvis, \& Rock N'Roll: A Cultural Revolution. The Journal of Undergraduate Research and Creative Activities for the State of North Carolina, 6, 95-104

McLelland, M. (2010). "'Kissing is a symbol of democracy!' Dating, Democracy, and Romance in Occupied Japan, 1945-1952". Journal of the History of Sexuality, 19 (3), 1-28.

Miller, J. (2004). The Outlier: Japan between Asia and the West. Asia-Pacific Center for Security Studies. 1-13

Murakami, H. (2000). Norwegian Wood. Translated by Jay Rubin. London: The Harvill Press.

Ritzer, G. (2011). Globalization: The Essentials. The United States: Wiley-Blackwell

Publication

Robertson, J. (2002). 'Blood Talks: Eugenic Modernity and The Creation of New Japanese'. History and Anthropology, 13 (3), 191-216

Rosenthal, M.. (2009). Cultures of Clothing in Later Medieval and Early Modern Europe. Journal of Medieval and Early Modern Studies, 39 (3), 459-481

Sakamoto, R. (2010). Pan-Pan Girls: Humiliating Liberation in Postwar Japanese Literature. PORTAL, 7 (2). 1-15

Schiller, H. (1976). Communication and Cultural Domination. International Journal of Politics, $5(4), 1-127$

Shillony, B. (1991). Politics and Culture in Wartime Japan. Oxford: Clarendon Press.

Sievers, S. (1983). Flowers in Salt: The Beginnings of Feminist Consciousness in Modern Japan. California: University of California Press.

Slade, T. (2009). Japanese Fashion: A Cultural History. New York: Oxford International Publishers Ltd.

Takemae, E. (2002). The Allied Occupation of Japan. London: Continuum. 
Tomlinson, J.. (1991). Cultural Imperialism. London: Continuum.

Yat-Him, T. (2011). Post-modern Sex and Love in Murakami Haruki's Norwegian Wood.

(Unpublished Thesis). The Chinese University of Hong Kong, Hong Kong.

Yoneyama, L. (2005). "Liberation under Siege: U.S. Military Occupation and Japanese Women's

Enfranchisement". American Quarterly, 57 (3), 885-910

Yoshimi, S. (2003). 'America' As Desire and Violence: Americanization in Japan. Inter-Asia

Cultural Studies, 4 (3), 433-450

Yoshitake, M. (2008). The Modern Language Ideology of English Pedagogy in Japan:

Intercultural and International Communication Consequence. (Unpublished PhD Dissertation).

The University of Oklahoma, the United States. 